\title{
Feminism between modern literature and literature in ancient times
}

\author{
Mouzah Salem Alhammad \\ The Public Authority for applied
}




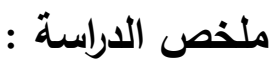

هدفت الدراسة النعرف على النسوية بين الأدب الحديث والأدب النسوي في العصور القديمة ، من خلال مكانه المرأة.

حيث أنشارت نتائج الدراسة إلى أن الآدبيات النسوية في العصور القديمة أظهرت مكانة

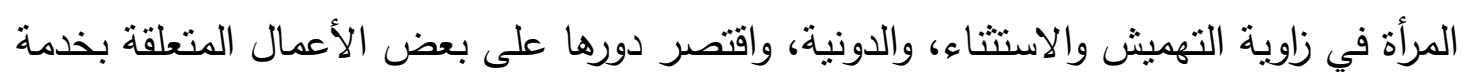

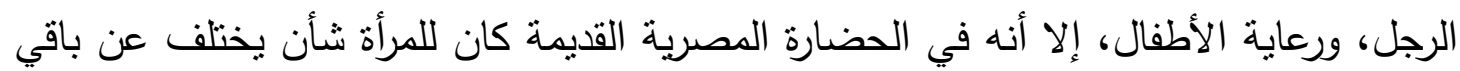

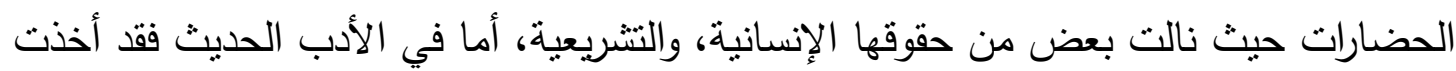
بعض النساء على عاتقها حمل مشعل النضال من أجل الحصول على حقوقهن ، وتحسين مكانة

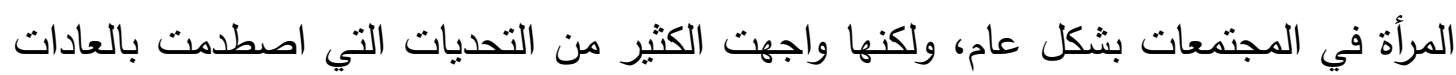

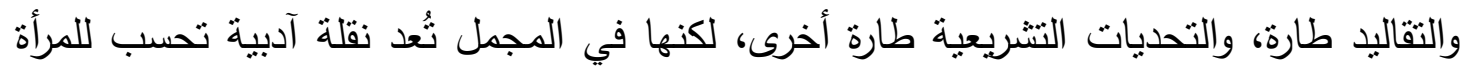
في العصور الحديثة في تحسين مكانتها بمجتمعها. 


\title{
Feminism between modern literature and literature in ancient times
}

\author{
Mouzah salem alhammad \\ The Public Authority for \\ applied education and \\ training- Kuwait
}

\begin{abstract}
:
The study aimed to identify feminism between modern literature and feminist literature in ancient times, through the place of women.

The results of the study indicate that the literature of women in ancient times showed the status of women in the corner of marginalization and exclusion, inferiority, and limited role on some work related to the service of men, and child care, but in the ancient Egyptian civilization was a woman is different from other civilizations, Human rights, and legislative. In modern literature, however, some women have taken upon themselves the burden of struggle to obtain their rights and improve the status of women in societies in general, but they have faced many challenges that have been challenged by customs and traditions. But in general it is a literary shift for women in modern times to improve their place in society.
\end{abstract}




\title{
Feminism between modern literature and literature in ancient times
}

\author{
Mouzah salem alhammad \\ The Public Authority for \\ applied education and training- \\ Kuwait
}

\section{Introduction :}

The speech of women as an individual in the society, in the context of claiming their rights from the perspective of their humanity - as a human being is important to men and helps them to manage the affairs of their societies as well as men, and human rights charters have granted them many rights in particular. The fact that many women have had similar and sometimes superior education to the education of men. If women have succeeded in many countries in the world to gain their human rights, they have the right to work, to vote and to run for political office, I soon realized that the activation of these rights was on Reality depends not only on the granting of the right, but is closely related to program those rights and a shift in the political, economic, social and cultural structures of the state and allow the realization of these rights and apply them.

Researcher examines the comparison between feminist literature in ancient civilization and feminist literature in the modern era in terms of the social status of women, as follows:

\section{First : Concept of Feminism:}

The first appearance of the term Feminism was in the literature of Western thought in 1895, and the concept of the term women's action on women's rights began with the end of the eighteenth century. The term feminism was officially adopted in 1910, Her prominent feminist contract, Klara Zatkyn, when he proclaimed March 8 as the International Women's Day, the date adopted by the League of Nations to commemorate the civil disobedience committed by New York workers in 1895 to protest the miserable conditions they suffered from, These workers. (Janet Todd, 2002, p. 66)

\section{Stages of Development of Feminist Literature :}

Women's literature has gone through different and overlapping stages so that today we are bold enough to present the female problems that women experience in Western societies in general, and Arab societies in particular, in relation to men, society, customs and traditions. To the most basic rights after being aware of itself and the world around it spent a lot of time, this struggle was in its beginnings from the inequality of the sexes to reach the needs of normal and easy, such as the right to education and work, and the right to choose the husband and other, and described the injustices on the female, Which was accompanied by an acronym The women's literature goes to a state of confrontation and rebellion against customs and traditions in the romantic stage, after the female awareness of 
the world around her was completed through education and out of the house, but this discourse has been leaning in many of its poverty on Men, the rebellious females need protection, and they do not give up, so gender equality is incomplete until this discourse in contemporary literary fiction turns to equal rights and duties after the social, economic and political transformations witnessed by the Arab world. (Atefah Faisal, $2005:$ 3)

Women's literature is based on several foundations :(Hirsch, Marianne, et al, 2005 : 9), (Gross, Elizabeth, 2002: 370)

1- Women are a category that can not be ignored and the protection of human rights is a women's base that focuses on women.

2- Focus on religion, race and culture is a threat to the unity of women in the world.

3- Liberalism is the ideal political language.

4- Feminist theory defines its materialism as the language. Language is the most important means of political resistance, the consolidation of identity and the affirmation of the status and role of women in the cultural system.

5- Feminism is an intellectual awareness, knowledge and civilization is different from women who are aware of sex and biology Feminist Versus Womanist.

\section{Second : Feminism in Ancient Literature :}

Despite the many writers and legislators in ancient Rome, they did not care about women, did not care about their rights but were assigned their duties. The women were in their eyes a legitimate nation in which the head of the family behaves as he does in his slaves. He held a meeting in Old Rome to discuss women's affairs, And decided that they have no soul or immortality and they will not inherit the afterlife and they are abomination and must not eat meat, and not laugh, and not speak, and must spend all their time in service, obedience, and have been sentenced to refrain from speaking.

The women were all from the highest families and the lowest walking in the streets and in her mouth a lock, and come and become in her home and in her mouth an iron lock, and this is the physical punishment that women were subjected to Because they are the tool of seduction and the fueling machine, and used by the devil to spoil the hearts, and they pour hot oil on the woman's body and tie it with the horses' tails and then run them with the fastest speed as they connect the vertebrae with columns and pour hot oil and fire on their bodies. Some members of the Romanian Council of Tarbum also forbade women to own $\mathrm{T}$ half ounces of gold, and not to wear different color clothes, and not to ride carts over a mile from Rome only in some public concerts. (VENERABLE J. A, et al., $2014: 84)$

women's literature in the Greeks depicted women as poisoned trees, and despised humiliating even to the abomination of the devil's work, and was like the fall of goods sold and bought in the markets, stolen rights, deprived of the right to inheritance and the right to dispose of money, and was in a very degenerate position. (William. J., O'Neal., 2001 : 116) 
It was not only that of ordinary men or ignorant people of the Greeks, it was also the view of wise thinkers, philosophers, and philosophers in this way, while the man was the wise man of all rights. This is the philosopher Aristotle, On the status of women in their society after analysis and thinking and says: Nature did not provide women with any reasonable mental readiness; therefore, should be limited to raising the affairs of household management, motherhood and nursery, etc., and then says: Three do not have to behave themselves: Will, and his child Erra The woman is a man who is not perfect, and has been left by nature in the bottom of the ladder of creation, "which is that women are men as slaves to the master, worker of the world, barbarians of Greece, and that men are higher than woman. (William. J., O'Neal., 2001 : 117-118)

Socrates said: "The presence of women is the biggest source and source of crisis and collapse in the world. The woman is like a poisoned tree, where it is beautiful, but when birds eat, it dies instantly. (Kay O'pry, $2012: 7$ )

Women's literature in the ancient Indian civilization was exposed to women's denial of their humanity and to the recognition of their social value, which meant that their rights were denied and burdened with many duties. Women in the ancient Indian society were worse than the plague, hell, poison, snakes and fire, So much so that he was reluctant to allow women to join the Buddhist community. (Vikas., et al., $2014: 21$ )

Thus, women in the Mano Law had no right to serve their husbands or fathers, and were not able to dispose of their property. They did not have the right to own property; all they owned belonged to their husbands or fathers, To her son. If her husband died, they burned her alive and buried her. Although British colonialism passed a law forbidding the burning of a woman alive with her dead husband, her life may be left to be sold with the husband's belongings. (Vikas., et al., $2014: 22$ )

In Persian women's literature, the Persian woman in Zoroastrianism was more fortunate than her predecessors. Zoroaster introduced a significant change in the attitude of the Persian society towards women. She enjoyed certain rights such as choosing a husband, opposing the father in marrying someone who did not like him, But the situation did not last long. When Zoroastrian era ended, the woman returned to the decline of her status, especially in the high classes that forced the woman to be locked in the house, and she was forbidden to see the man, even if he was a father or a brother. , And poor women have lost I took some of those rights, and because of that in the eyes of the Persian society despised pariah, and remained this gross disregard for the Persian man a profuse amount; as he was insolent daughter and sister, sister and sister, and allows the mother, and combines the two sisters. (Massoume, 2017)

In the Babylonian and Assyrian feminist literature, which showed that the laws were more severe for women, the literature did not disclose any details about the lives of ordinary women - or ordinary men - but of course knew more about men's lives just because more men were in power, On the status of women in 
ancient Assyria comes from administrative documents and codes of law, paints a picture of women as belonging to men in all spheres of life, and evidence that women have been punished not only for abuses committed by themselves but also for crimes committed by their descendants, "The And that the woman's physical health depends on the whims of her husband, and the text of the law: A man can flog his wife, uproot her hair, cut her ears, or beat her, There were no penalties for his behavior towards women, and their treatment by the law and by their men seemed to be more brutal. (Robert Bain, 2017)

In the law of Hammurabi, women were considered as sinners, and they were not entitled to property or behavior. If a man kills another man's daughter, he must hand him over to his daughter to kill her or steal them according to his will, according to Hamorabi's law. (James $C$. Thompson, 2010)

The woman has distinguished herself in the literature of the ancient Egyptian civilization over its predecessors in terms of women's status. The king ruled her and her wisdom in individuals and groups. She regulated the laws, ran political affairs, gained full financial rights and acted completely without censorship or stone. In many cases, polygamy was not permitted, but in special cases, such as a wife's illness or inability to have children. If the husband died, the authority was transferred to the children who had not attained the age of majority, even in the family relations of the state, But the law And the husband was forced to marry his sister, with the intention of placing his hand mostly on their wealth and property because all the agricultural property was their right. (James $C$. Thompson, 2010)

\section{Third : Feminism in modern literature:}

Individual efforts evolved into organized movements of many women and encouraged by some writers and politicians. In 1866, the philosopher (John Stuart Mill) submitted a request to establish the first women's association in Britain to give them the right to vote in parliament. Women considered that this right was the most important right to be achieved by providing them with the platform through which their voices could be communicated to the Government on other demands. Among those who signed the Order (Florence Nightingale), 1820-1910, Crimean war (the war between the Ottoman Empire and Russia in 1853). (Omar Sulaiman Al-Ashqar, 1988)

However, in 1918, women did not get the right to vote in Britain, and for those over the age of 30, and after many women's demonstrations that were not without confrontations and clashes with the authorities, in 1909 women activists began to bypass the law and burning property, The women in front of the king's horse in the famous derby race and killed in 1912, and broke the glass of the buildings of the ministries, such as the interior, the war and the foreign during the demonstrations, hundreds of women were arrested and sentenced to prison for food, and the prison doctor enters the food to the stomach of the hunger striker by tube and insulting Despite this, and when public opinion raged on these measures, the authorities began to resort to the method of releasing the hunger striker when 
she becomes ill health and then returned to prison when her health improves, and the clashes with the Authority stopped at the beginning of World War I when the attention of the feminist movement to the war and then The war gave women the right to vote. (Omar Sulaiman Al-Ashqar, 1988)

In 1913, the United States of America was renamed the Movement for the Liberation of Women, the first of which was the Jewish women movement. It was one of the most important principles on which the woman and her personality were founded. The most important reasons for the exclusion and marginalization of women were the inferiority of women The rabbis were in control of the past centuries, not only for religious life but also for Jewish public life, where their views became Prevailing between Jews, and their judgments are the window and influence in their lives and had a great impact on the Jewish community itself, and became a male-dominated male society, was not allowed to be a woman, a rabbi, or a synagogue or assigned responsibilities, and was not even allowed to But they are not allowed to learn or learn religion, nor are they allowed to divorce without the consent of their husbands and their consent to give them the book of divorce with their hands as stipulated in the Torah. Many texts in Jewish religious heritage books confirm this situation. (S.Sheridan, 1994)

The Rabbis' view of the inferiority of women was also reflected in several issues that the women's movement took upon them and criticized them, including what they described in inappropriate descriptions, describing them as arrogant, and spreading to rumors and conversations of disbelief and gossiping. For pleasure, and they said about her creature is trivial and tired, and her sexual desire has no limits, and that if she did not give a job to occupy herself, and watching from afar they escape the mind, and out of control, they considered her sexual desire is extremely dangerous must be monitored and careful and control On them, and that anyone speaks so much And with women they bring evil to themselves and violate the Torah and enter hell. "Their statements in women also say that walking behind the lion is more peaceful than walking behind a woman. (S.Sheridan, 1994)

The women's movement criticized the rabbis for denying them the right to education and learning. The emphasis was on the education of male children over the past centuries. In the Talmudic letter, Kadoshim (A and B), the Talmud states that "duties towards religion are imposed on the father, not on the mother, (6/4) "Hear, O Israel, teach them to your children." Here the rabbis interpreted this text that education is limited to children without girls. There is no order to teach girls, and women should not teach themselves or Inform others. (S.Sheridan, 1994)

The rabbis ordered the father not to teach the Torah to the girls, because the most women never intended to learn anything, and because of their poor understanding, they would turn the Torah's words into meaningless things," said the rabbi and philosopher (Moses Maimonides). He is "every person knows his daughter Torah is like those who teach them trivial things. (Talmud Torah)

Political feminism was reflected in the second phase of women's liberation 
in Britain and the United States of America by drawing attention to a new kind of knowledge on women's issues. (Arneil, Barbara, 1999: 118)

A group of the First Women's Movement called for women's identity and the problems of granting their rights away from biological identity, because women are not, in their totality, a homogenous group similar to circumstances, demands and goals. The former feminists called themselves Feminists, At the head of the Movement for the Liberation of Women in Europe, which demanded the liberation of blacks and children, and approached her views with the Socialist Women's Movement in demanding the abolition of class and qualitative discrimination.

Feminist activists have contributed to the spread of what is known as women's culture and reflect the different conditions and forms of women's resistance to power in the public and private spheres. They are more general and comprehensive than women's culture, which are based on traditional local elements such as customs and religion. Women's culture reflects elements of women's culture, Care and upbringing, however, they reject biological determinism, and affirm the feminist culture on collective and cooperative rejection of hierarchy and competition as a male ethic. (Taylor et al., 2007)

Carol Quillen has developed a feminist concept based on the existence of human foundations and capabilities that must be met, respected and developed globally, such as the commitment to women's social and political equality within the framework of global justice against all forms of political oppression and economic exploitation. Females give value to personal experience and reject the traditional distinction between objectivity and objectivity in the context of "personal is politics". Social systems and structures, whether they concern the family, the economy or women, have political connotations. (Carol Quillen, 2001)

Professor Andersson points out that Swedish women have succeeded in achieving many of their legitimate rights over the last century. "But there are many rights that have not yet been achieved, including equality between men and women in the labor market and salaries. Women are still the weakest element in society because they have to reconcile. Between their work and their domestic duties, without considering it as work that requires effort and time. These and other issues may constitute a basis for the future political project of women in Sweden if a feminist party is established. "Where the Swedish women succeeded in 1632 in the establishment of the first school for girls in the city of Vestros, and in 1748, the Academy agreed to the entry of Ms. Eva Dola Garda Akbalad to the Council to become a member and followed by the Technical Academy in the appointment of Ms. Alracha Bash member and in the same year, A woman's newspaper entitled "What's new, what's new", but Swedish women did not get their inheritance right until 1845. A single woman over the age of 25 received her right to be considered an adult before society and law, To the court but when she married, she was prostrating D to be placed as a non-adult human. (Qassem 
Hammadi, 2005)

In 1859 Swedish women were able to enter the field of teaching. The schools allowed women, even a few, to work as teachers. In 1862, women were allowed to vote, provided that they met the conditions of financial income. In 1864, The Nobel Committee for Literature honored the Swedish writer Salma Lagrlov of the Nobel Prize for Literature in 1909 and culminated in the Swedish women years of struggle with the right to vote and to stand in the right to vote. Year 1919. (Qassem Hammadi, 2005)

The political process began with the departure of the Left Party in the Swedish parliamentary elections, declaring that it had separated from the party so that it could study the experiences of the women's parties in the world. Although most of them failed, there are parties that succeeded and continue in political work to this day. Among these parties is the Women's List in Iceland, a women's party that entered parliament in 1983 and remained there until 1999. There are also successful women's parties in Lithuania, Armenia and Northern Ireland. (Qassem Hammadi, 2005)

The post-World War II cultural analysis highlighted the political, economic, and institutional characteristics of postmodern societies and created new forms of social movements. The field of politics and economy was no longer the domain of power practices alone. Other knowledge fields of power, such as race, And developed around these fields of knowledge of theories and then new cultures, including the feminist movement and its activists, and distinguish "Katzenstein" between two types of activists in the feminist movement :

- Activists of interest groups, aiming to influence the political elite, and then political decisions and legislation.

- Activists use cultural discourse mainly and benefit from writings that reflect the supremacy of masculine discourse without other types of discourse.

The latter type is the most widely used by feminists, which led to the emergence of feminist discourse and resistance to the discourse of masculine and aims to change the prevailing cultural and social structures that cause the oppression of women and acquire the legitimacy of beliefs and customs.

Women in the eyes of women are not treated equally and do not get their rights in societies that regulate their affairs and determine their priorities according to the vision of the man and his interests, nothing but a woman. In this patriarchal model, women become everything that does not discriminate against men, Men are strong, women are weak, men are rational, women are emotional, men are women and women are passive. (Razan Mahmoud Ibrahim, 2008)

Women are everywhere in the negative and denied the right to enter public life and to play their role in the fields of culture, politics, economics, men and even with them. It is thus possible to say that feminism is a movement that works to change these conditions to achieve this absent equality. They have the truth, they try to say that men do not take it. (Nazek al-Araji, 1997)

Feminism insists that this injustice is neither permanent nor inevitable, and 
that women can change the social, economic and political system through collective action, and thus women's efforts are aimed at improving the status of women in society. The idea that a man can adopt a feminist position is controversial; for example, Mudelski distinguishes between the contribution of men who involve the analysis and dissolution of masculine authority, and the man who speaks on behalf of women or from the position of women. (Nazek al-Araji, 1977)

In the study of literature and culture, feminist criticism takes the form of analyzing the mechanisms of production and consumption of specific texts or practices from a feminist perspective. There are different ways of addressing them, all women, all of which allow for pluralism within the framework of different knowledge and feminism itself. "Feminism is a multi-faceted cultural and historical movement, and its goals have been supported worldwide," says Maggie Ham. "The effectiveness of feminism can be assessed if we look at women's discourse and how well it penetrates thinking at the level of women. Everyday life. (Nazek al-Araji, 1977)

(Mustafa) mentioned that in the 1960s there was activity in the feminist movement. There were three factors that contributed to the new wave of women's movement activity: the general atmosphere of critical thinking that characterized the period, and the anger of the active women leaders who rallied to support Antiwar movements, the movement of civil rights, student movements and discrimination against women's entry in large numbers into paid employment and higher education. For these reasons, the new women's movement continued to expand during the 1970s and 1980s. DONC and Ojhin in these years have become an international phenomenon. (Mustafa Khalaf, 2009)

Feminist movement on several grounds, the most important of which : (Hirsch, et al., 1994), (Gross, 1994)

1- Women are a category that can not be ignored and the protection of human rights is a women's base that focuses on women.

2- Focus on religion, race and culture is a threat to the unity of women in the world.

3- Liberalism is the ideal political language.

4- defines the feminist theory of materialism and language is the language, the most important means of political resistance and the consolidation of identity and emphasize the status and role of women in the cultural system.

5- Feminist theory refuses to be the product of historical and political developments.

6- Feminism is an intellectual awareness, knowledge and civilization is different from women who are aware of sex and biology.

\section{Discussion and results :}

Women's literature in ancient times refers to the exception of the role of women in society, as evidenced by some evidence that their lives were restricted and hidden in other respects also, although the customs vary from place to place. 
Ancient literary writings in different cultures, the myth of the inferiority of women and the negation of the deconstruction of values associated with femininity, are reminiscent of the absolute truth that has historically formed the solid nucleus of the literary, intellectual, moral and ideological discourse prevailing today. (Nasr Hamed Abuzeid, 1994)

Women participated in ancient civilizations in one place, except for the ancient Egyptian civilization, which was characterized by the other civilizations at that time in the empowerment of women from some of the rights taken from their sisters in some other civilizations, in addition to what was given by the Zoroastrian religion in Persia.

These practices against feminism in ancient civilizations have resulted from the lack of literary production of women in these civilizations, as opposed to men, where feminists share the goal of freeing women and improving their status. Their goals go beyond giving women equal opportunities in men and women to change the structure of society In order to improve the status of women structurally, and despite the agreement on the goal, but the difference lies in the means and mechanisms necessary to achieve this goal.

This explains the violent psychological and social tensions in modern civilizations that sweep the literary and literary writings at every moment when the issue of the status of women in society is raised. This issue is problematic for public debate in various Arab and Islamic societies, where the majority believes that changing the status of women In private or public life constitutes a threat to the cultural identity of the national, national or religious group.

It is a means to modernize the roots of Arab society by putting the potential of educated women in the service of the needs of the family as a first social institution, and gives modernist theorists great importance for modernizing the role of women. As a wife and mother, and the impact on the education of generations of young people in scientific ways, and meet the needs of educated men in wives shared by the exchange of views and agreement in the stripes, in this context, Arab women educated role of the community, especially in the middle class. (Mervat Hatem, 2001)

Human rights and fundamental freedoms are rights acquired by individuals from birth. The protection and development of these rights is the primary responsibility of governments. International human rights instruments affirm that all human rights, political, civil, social and economic are universal and interrelated, as expressed in the Vienna Declaration (1993) And the Program of Action of the International Conference on Human Rights. (United Nations Document, 1993)

The leader of the English feminist movement, Elizabeth Stanton, confirmed that the man was cruel, egotistical, violent and arrogant. He loved evil, violence and destruction. In the 20th century, most Western feminist movements tended to put men in the grip of the old age. In this regard, the issue became a topic of concern, and the family itself received many of the effects of this battle, 
including the refusal of motherhood and childbearing, the rejection of the family itself, the disintegration of the family itself, the permissibility of abortion and homosexuality, and the abolition of the father's role. And For habitation and the distribution of roles. (Ali Mohiuddin Karra Daghi, 2006)

Qasim Amin said that since the late 19th century, the discussion of the emancipation of women in the writings of men and women has been associated with the call to modernize Arab societies. In this modern discourse, women's education occupies a special place in explaining the backwardness of women in prehistoric society, And social, economic and political problems. This discourse provided education as a prerequisite for women's participation in the management of their society. In contrast, women had to use their education primarily in the upbringing and education of their children on scientific grounds, Here is the learner's interests home. (Qasim Amin, 1984)

Women and their issues have become a tool in some countries that have used them as a winning political tool, increasing the representation of some parties or governments that use their rights and working to improve the status of women in societies. These governments and political parties have political gains in the political street to adopt women's issues and equity in societies Like women in the Third World, and women should wear men's suits to enter those parties, to embrace the political waves so as not to be accused of weakness, and the political variety as a woman whose physical abilities are not compatible with the men and do not equal with them in the right And duties, as seen in some third world countries.

any case, it is problematic, formed over a long time and will not be understood dimensions and the dismantling of elements and overcome the negative effects on the individual and society, the state and the nation only gradually and over a long time as well, and modern writings in various forms of rhetoric and literary knowledge played and will play a constructive role in This trend.

Some writers and jurists believe that there are no special or distinct rights for women. They consider that family rights, reproductive rights and the right to protection against domestic violence do not necessarily constitute rights for women. Although most victims of domestic violence are women, this does not make the right to protection limited only to women, just as the right to collective bargaining is not exclusive to men because most union members are men. The principle in each case is independent of gender and gender considerations. (Jack Donnelly, 2003)

In light of the above, the researcher concludes that if the family is the way to modernize society at present, according to our Arab societies, the needs of women as individuals should be taken seriously, and women's needs should be taken seriously. The right of women to work outside the home, their right to rise to administrative centers, political representation, real equality between men and women and the recognition of equality in partnership with society, such as 
modern societies, from which we take many modern technology. It is a social structure, it is regulated and it is consistent with our traditions and customs.

The current situation in the Arab family, especially those where men leave and women also graduate from work outside the home. Then, women alone face additional work that requires childcare, housework without any help from men, which establishes equal relations within the family. Women must take the initiative. In criticizing the discourse of modernity, and not emphasizing the modernization of the role of women as mothers and wives and their stature in terms of modernizing the role of men as father and husband, and can initiate the process of negotiation and change in these roles within the family to build a society that reflects the aspirations and needs of men and women together.

\section{Reference}

[1] Ali Mohiuddin Karra Daghi (2006): Women, Political Participation And Democracy Study In Islamic Jurisprudence And Islamic Thought, Research Presented To The 16th Session Of The European Council For Discipline And Research, P. 22.

[2] Arneil, Barbara (1999): Politics And Feminism: An Introduction, Oxford, Malden Mass, Blackwell, P:118. 
[3] Atefah Faisal (2005): Transformations Of Feminine Discourse In The Feminist Novel In Syria, Damascus University Journal, Vol. (21), No. (1 + 2), Syria.

[4] Carol Quillen (2001): Feminist Theory: Theory, Justice And The Lure Of The Human. Journal Of Women In Culture And Society, Signs, Vol.27, No.1, Autumn, P:85

[5] Gross, Elizabeth (1994): What Is A Feminist Theory, In Knowing Women, University Of California, P. 370

[6] Gross, Elizabeth (2002): What Is A Feminist Theory, In Knowing Women, P. 370.

[7] Hirsch, Marianne And Valerie Smith (1994): Feminism And Cultural Memory, Journal Of Women And Culture, P.9

[8] Jack Donnelly (2003) : Universal Human Rights In Theory And Practice, Cornell University Press, Ithaca And London, P.212.

[9] James C. Thompson, (2010) : Women In Babylonia Under The Hammurabi Law Code, Http://Www.Womenintheancientworld.Com/Index.Htm (9/10/2017)

[10] Janet Todd (2002): Defending Feminist Literary History; Translated By Reham Ibrahim, National Project For Translation, Supreme Council Of Culture, Cairo.

[11] Qassem Amin (1984): Women And New Women, Arab Center For Research And Publishing, Cairo.

[12] Kay O'pry (2012) : Social And Political Roles Of Women In Athens And Sparta, Saber And Scroll Journal, Vol. (1), No. (2).

[13] Massoume Price (2017) : WOMEN'S LIVES IN ANCIENT PERSIA, Pars Times, Greater Iran \& Beyond, Http:// Www. Parstimes. Com/ Women/ Women_Ancient_Persia. html (8/10/2017)

[14] Mervat Hatem (2001): The Discourse Of Modernity And The Problematic Situation Of Women In Arab Societies After 100 Years Of Change, Arab Affairs, P 105, Cairo.

[15] Mustafa Khalaf Abdul Gawad (2009): The Theory Of Contemporary Sociology, Dar Al-Masirah, Jordan

[16] Nasr Hamed Abuzeid (1994): Women In Crisis Speech, Dar Nasos, Cairo.

[17] Nazek Al-Araji (1997): Female Voice: Study In Arabic Feminist Writing; AlAhli Magazine, 1, Damascus, Syria.

[18] Omar Sulaiman Al-Ashqar (1988): Women Among The Preachers Of Islam And Advocates Of Progress, Dar Taibah, 5, Riyadh. K.S.A.

[19] Qassem Hammadi (2005): Qassem Hammadi (2005): Women Pioneers Of The Women's Movement: From Education To Rights In Politics, Al-Hawar AlMu'madin Magazine, Issue 1092The Swedes Pioneers Of The Women's Movement: From Education To Rights In Politics, Al-Hawar Al-Mu'madin Magazine, Issue 1092, Http:// Www. Ahewar. Org/ Debat / Show. Art. Asp? Aid $=30671 \quad(5 / 10 / 2017)$

[20] Razan Mahmoud Ibrahim (2008): Feminism In Literature And Criticism, Jordanian Journal Of Arabic Language And Literature, No. 1, Volume 4, Jordan. 
[21] Robert Bain., (2017) : Women, Fundamentalism And Terror: Echoes Of Ancient Assyria, Http://Www.Womenintheancientworld.Com/Introduction.Htm $(4 / 10 / 2017)$

[22] S.Sheridan (1994): Hear Our Voice, SCM Press, London, P. 93.

[23] Taylor, Verta And Nancy Whittier (2007): Analytical Approaches In Hank Johnston, Social Movements And Culture, P. 169.

[24] United Nations Document (1993): Vienna Declaration And Program Of Action Of The International Conference On Human Rights, Vienna, 14-25 June, Human Rights Library, University Of Minnesota, P. 123.

[25] Venerable J. A. Hessey, D.O.L Archdeacon Of Mid-Dlesex, (2014) : A History Of Roman Literature? Charles Thomas Cruttwell, Oxford.

[26] Vikas Nanda \& MS. Rajnish., (2014) : Status Of Women Through Ages In India, International Research Journal Of Social Sciences, Vol. (3), No. (1), India.

[27] William . J., O'Neal., (2001) : The Status Of Women In Ancient Athens, International Social Science Review Journal, Vol. (68), No. (3), U.S.A. 